\title{
Clinical Presentation of Cholesteatoma- A Study of 50 Cases
}

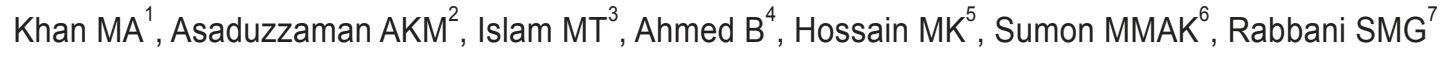

\begin{abstract}
Introduction: Cholesteatoma is an abnormal accumulation of keratin-producing squamous epithelium in the middle ear, epitympanum, mastoid or petrous apex. It is a threedimensional epidermoid structure exhibiting independent growth, replacing middle ear mucosa, resorbing and replacing underlying bone. Although it is not a neoplastic lesion, it can be insidious and potentially dangerous to the patient.
\end{abstract}

Objective: To find out the socio-demographic pattern, clinical presentation and complication of cholesteatoma.

Materials and Methods: This prospective study of 50 cases was done in the Department of Otolaryngology and Head-Neck surgery, $\mathrm{CMH}$, Dhaka adopting simple random sampling technique from July 2008 to Dec 2009. Data were collected by personal interview and clinical examination in a pre-designed data sheet and were analyzed by SPSS 20 .

Results: In this study, the highest number of patients (44\%) was in the age group 11-20 years with a mean age of 17.2 years. Male were more affected $(70 \%)$ and the male to female ratio was 2.33:1. Commonest symptom was otorrhoea $(100 \%)$, followed by hearing impairment $(80 \%)$, otalgia $(16 \%)$, postauricular painful swelling $(12 \%)$ and postauricular discharging sinus (10\%). Extracranial complications were in $26 \%$ and intracranial complications in $12 \%$ of patients in this series. Abscess (temporal lobe + extra dural) were found in 02 cases (10\%) by CT scan. A maximum number of patients had moderate conductive deafness $(74.47 \%)$ followed by mild conductive deafness $(19.15 \%)$ and only a few with severely mixed deafness $(6.38 \%)$.

Conclusion: Clinical presentation of cholesteatoma in this study was discharge and deafness. The discharge was thick purulent foul smelling, scanty, occasionally blood-stained. Grave intracranial complications in children developed because of illiteracy, poverty, lack of awareness and medical facilities mostly in the rural areas. So early diagnosis and prompt treatment was a necessity.

Key-words: Cholesteatoma, Neoplastic lesion, Clinical presentation, Complications, Socio-demographic pattern.

\section{Introduction}

Cholesteatoma is the end stage of (squamous epithelial) retraction of the pars tensa or flaccida that are not selfcleansing, retain epithelial debris and elicit a secondary, inflammatory mucosal reaction ${ }^{1}$. A slowly progressive and destructive disease of the middle ear cleft capable of destroying soft and hard tissue surrounding it, which is a common finding in otological practice ${ }^{2}$. The attico-antral disease appears histologically with three components, the cystic content, the matrix and the perimatrix. The perimatrix layer is in contact with bone and the granulation tissue, produces various proteolytic enzymes that may result in bone destruction ${ }^{3}$. Cholesteatoma may be congenital and acquired. Again, acquired cholesteatoma may be primary and secondary ${ }^{4}$.

In three varieties of Acquired chronic active squamous otitis media (cholesteatoma) the most common form is primary acquired chronic active squamous otitis media which retained keratin debris accumulates ${ }^{5}$. Another type, the secondary acquired chronic active squamous otitis media that is retained within the middle ear, mastoid or both. Third varieties of acquired chronic active squamous otitis media where the mucosa undergoes metaplasia to squamous type ${ }^{6}$.

1. Lt Col Md Ahsanuzzaman Khan, MBBS, FCPS, MCPS, DLO, Classified Specialist in Otolaryngology and Head-Neck Surgery, CMH, Dhaka 2. Col AKM Asaduzzaman, MBBS, FCPS, MCPS, DLO, Classified Specialist in Otolaryngology and Head-Neck Surgery, CMH, Dhaka 2. Lt Col Md Tauhidul Islam, MBBS, FCPS, MCPS, DLO, Classified Specialist in Otolaryngology and Head-Neck Surgery, CMH, Dhaka 3. Lt Col Bashir Ahmed, MBBS, FCPS, MCPS, DLO, Classified Specialist in Otolaryngology and Head-Neck Surgery, CMH, Dhaka, 4. Lt Col Mohammad Kamal Hossain, MBBS, FCPS, MCPS, DLO, Classified Specialist in Otolaryngology and Head-Neck Surgery, CMH, Dhaka 5. Maj Mohammad Misbah Al Kabir Sumon, MBBS, FCPS, DLO, Classified Specialist in Otolaryngology and Head-Neck Surgery, CMH, Momenshahi 6. Maj Sarder Mohammad Golam Rabbani, MBBS, FCPS, Classified Specialist in Otolaryngology and Head-Neck Surgery, Adhoc CMH, Ramu. 
Clinical presentation of chronic active squamous otitis media (cholesteatoma) in an uncomplicated case is usually discharge and deafness, the discharge is thick purulent foul smelling, scanty, occasionally bloodstained ${ }^{7}$. This can be often asymptomatic, only discovered as an incidental finding. However, with the presence of complications patient develop earache, fever, chill and rigor, postauricular swelling, vomiting, vertigo, headache, postauricular discharging sinus, facial weakness etc ${ }^{8}$. In our country many cases with chronic active squamous otitis media (cholesteatoma) present with extracranial complication and sometimes with grave intracranial complications specially in case of children because of illiteracy, poverty, lack of awareness and lack of medical facilities mostly in the rural areas. As chronic active squamous otitis media (cholesteatoma) is considered unsafe because of the risk of complications, particularly intracranial complications, early diagnosis and treatment is essential for the safety of patients ${ }^{9}$.

Throughout the early half of the 20th century, Cholesteatoma was managed by radical mastoidectomy or exteriorization. Over the last couple of decades, otologic surgeons have migrated to a more conservative mastoidectomy approach. Most otologic surgeons now perform techniques depending on the individual circumstances of a particular patient ${ }^{10}$.

\section{Materials and Methods}

This was a prospective study done on 50 cases adopting simple random sampling technique and was conducted in the Department of Otolaryngology and Head-Neck surgery, $\mathrm{CMH}$, Dhaka, Dhaka cantonment from July 2008 to Dec 2009. The inclusion criteria for this study were chronic active squamous otitis media and exclusion criteria were mucosal otitis media, cholesteatoma, CSOM with scanty foul smelling discharge, CSOM with attic perforation.

\section{Results}

A total of 50 cases were included in this study and, all the information were compiled and presented in the form of tables and figure as shown below.

Table-l: Distribution of patients by age $(n=50)$

\begin{tabular}{|c|c|c|}
\hline Age (in years) & Number of patients & $\%$ \\
\hline $0-10$ & 10 & 20 \\
\hline $11-20$ & 27 & 44.0 \\
\hline $21-30$ & 08 & 16.0 \\
\hline $31-40$ & 05 & 10.0 \\
\hline$>40$ & 0 & 0.0 \\
\hline
\end{tabular}

Table-I shows that the age range of the cases studied was from 6 years to 40 years. The youngest patient presented with cholesteatoma was 6 years old and the eldest patient was 40 years old. The average age is 17.2 years. Male is more affected $(70 \%)$ than female $(30 \%)$. The ratio of male and female is $2.33: 1$.

Table-II: Distribution of patients by educational status $(n=50)$

\begin{tabular}{|l|c|c|}
\hline Educational status & Number of patient & $\%$ \\
\hline No education & 11 & 22 \\
\hline Primary education & 20 & 40 \\
\hline Secondary education & 09 & 18 \\
\hline Higher secondary education & 06 & 12 \\
\hline Graduation & 04 & 8 \\
\hline
\end{tabular}

Table-Il shows that the patients either having no education group $(22 \%)$ or having primary education $(40 \%)$ are mostly suffering from cholesteatoma (Active squamous chronic otitis media) in this series.

Table-III: Distribution of patients by clinical presentation $(n=50)$

\begin{tabular}{|l|c|c|}
\hline Symptoms & Number of patient & $(\%)$ \\
\hline Discharge from ear & 50 & 100 \\
\hline Hearing impairment & 40 & 80 \\
\hline Earache & 08 & 16 \\
\hline Fleshy mass in ear & 07 & 14 \\
\hline Post auricular painful swelling & 06 & 12 \\
\hline Post auricular discharging sinus & 05 & 10 \\
\hline Fever & 05 & 10 \\
\hline Headache & 05 & 10 \\
\hline Vomiting & 03 & 06 \\
\hline Vertigo & 02 & 04 \\
\hline Neck rigidity & 02 & 04 \\
\hline Facial paralysis & 01 & 02 \\
\hline Tinnitus & 01 & 02 \\
\hline Imbalance & 01 & 02 \\
\hline
\end{tabular}

Almost all the patients presented with more than one symptom. Commonest symptoms were otorrhoea (100\%), followed by hearing impairment $(80 \%)$, otalgia $(16 \%)$, postauricular painful swelling (12\%) and postauricular discharging sinus (10\%). A few patients complained about tinnitus (2\%) and imbalance (2\%) (Table-III).

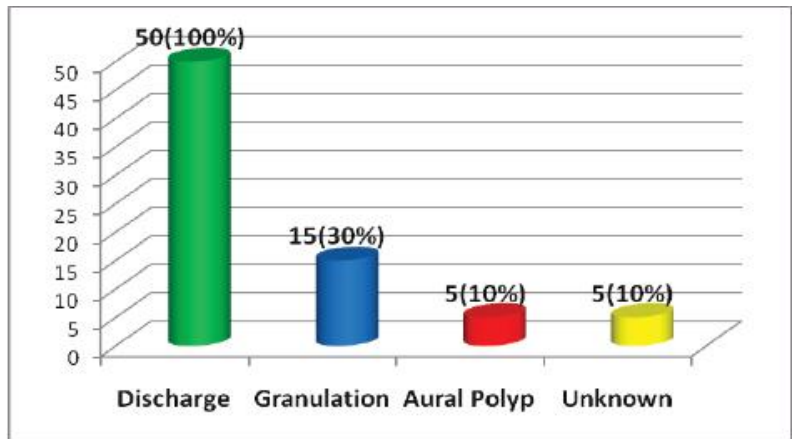

Fig-1: Distribution of patients by the condition of the external auditory canal $(n=50)$ 
Table-IV: Distribution of patients by character of discharge ( $n=50$ ears)

\begin{tabular}{|c|c|c|c|c|c|}
\hline \multicolumn{2}{|c|}{ Smell } & \multicolumn{2}{|c|}{ Amount } & \multicolumn{2}{c|}{ Colour } \\
\hline Malodourous & Odourless & Scanty & Profuse & Blood stained & Pearly white \\
\hline 50 & 0 & 40 & 10 & 10 & 40 \\
\hline
\end{tabular}

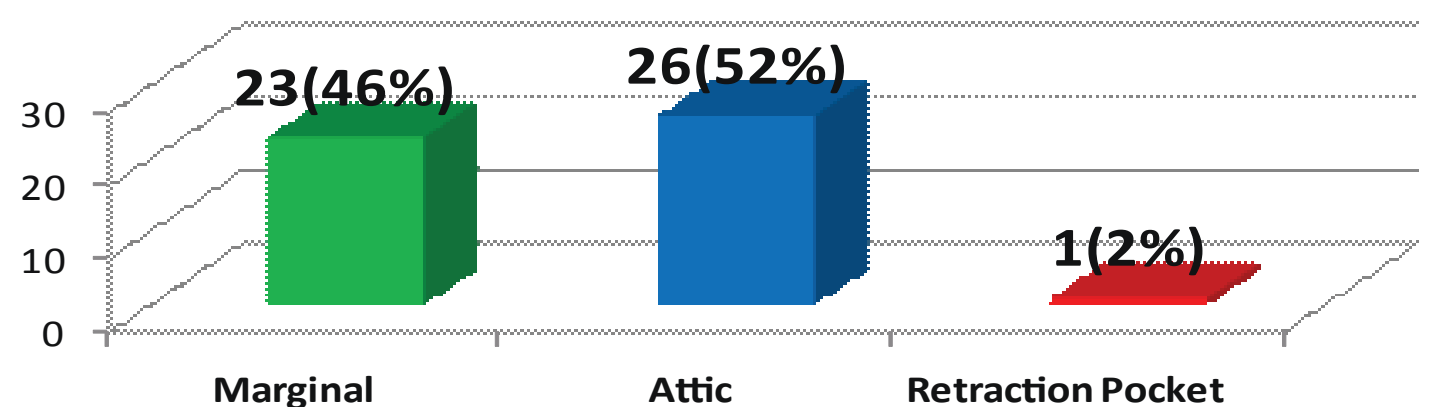

Fig-2: Distribution of patients by site of perforation and retraction pocket in attic region of tympanic membrane $(\mathrm{n}=50)$

Table-V: Distribution of cholesteatoma (Active squamous chronic otitis media) patients by complications $(n=50)$

\begin{tabular}{|l|c|c|}
\hline Complications & Number of patients & Percentage \\
\hline Postauricular abscess & 06 & 12 \\
\hline Postauricular Sinus & 05 & 10 \\
\hline Facial palsy & 02 & 04 \\
\hline Extradural abscess & 01 & 02 \\
\hline Lateral sinus thrombophlebitis & 01 & 02 \\
\hline Meningitis & 03 & 06 \\
\hline Temporal lobe abscess & 01 & 02 \\
\hline
\end{tabular}

Table-VI: Distribution of patients by the site of cholesteatoma (per-operative findings) ( $n=49$ ears)

\begin{tabular}{|l|c|c|}
\hline Site and extention of cholesteatoma & Number of Ears & Percentage \\
\hline Attic + Aditus + Middle ear & 11 & 22.44 \\
\hline Attic + Aditus + Antrum + Middle ear & 14 & 28.58 \\
\hline Attic + Aditus + Antrum + Mastoid + Middle ear & 24 & 48.98 \\
\hline
\end{tabular}

Table-VII: Distribution of patients by findings of CT scan of temporal bone and brain $(n=20)$

\begin{tabular}{|l|c|c|}
\hline Findings & Number of Cases & $\%$ \\
\hline CT scan of ear:- circumscribed cavity with ossicular erosion & 18 & 90 \\
\hline CT scan of brain:-Space occupying lesion & 02 & 10 \\
\hline
\end{tabular}

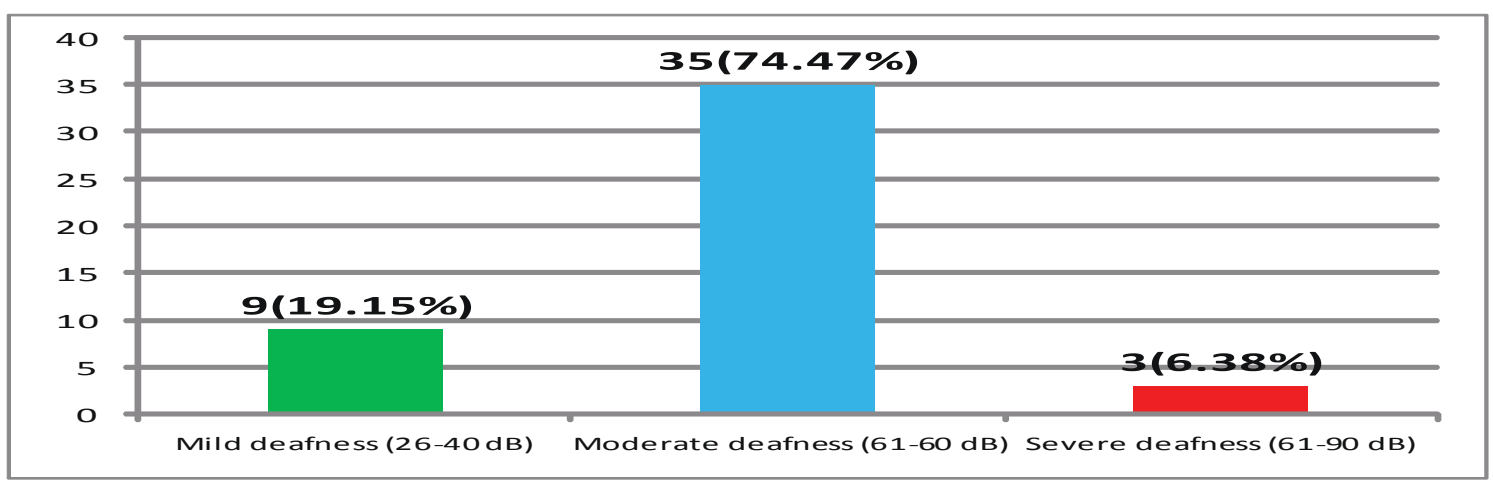

Fig-3: Audiological findings of cholesteatoma (Active squamous chronic otitis media) patient ( $\mathrm{n}=47$ ears). 


\section{Discussion}

In this study, the highest number of cases belongs to the age group of $11-20$ years (44\%). The youngest patient in this series was 6 years old and the eldest patient 40 years old (Table-I). Study done by Shenoi PM and Cody TR et al found that youngest patient was 04 years old and eldest patient was 55 years old ${ }^{11,12}$. In this series, the educational status shows that most patients are from either in the illiterate group $(22 \%)$ or in primary education group (40\%). This reflects the higher incidence of cholesteatoma (Active squamous chronic otitis media) in illiterate and low-educated people (Table-III). Other study done by Ludman $\mathrm{H}$ and Chowdhury MA et al revealed that most of the patient $(52 \%)$ with cholesteatoma was illiterate ${ }^{13,14}$.

Almost all the patients presented with multiple symptoms otorrhoea $(100 \%)$ was the commonest symptom to present with, followed by hearing impairment $(80 \%)$, otalgia $(16 \%)$, some fleshy mass $(14 \%)$ in the external auditory meatus, postauricular discharging sinus $(10 \%)$, $26 \%$ of patients presented with extracranial complications and intracranial complications were $12 \%$ of patients (Table-VI). Study done by Kangsanarak $\mathrm{J}$ et al found that most of the patients $(89 \%)$ were presented with ear discharge and intracranial complication $(7 \%)$ which is not similar with this study ${ }^{15}$.

In this study, it is seen that cholesteatoma (Active squamous chronic otitis media) involved right ear in $56 \%$ of cases and left ear in $44 \%{ }^{12}$. Otoscopic exammation of middle ear shows discharge in $100 \%$ cases, granulation tissue in $15 \%$ cases and sagging down of posterosuperior canal wall in $5 \%$ cases (Figure-1). The discharge was foul smelling $(100 \%)$ scanty $(80 \%)$, pearly white $(80 \%)$ and bloodstained (20\%) (Table-VII). Ludman $\mathrm{H}$ found in his study that foul smelling ear discharge $(98 \%)$ and granulation tissue $(10 \%)^{12,13}$.

About the condition of the eardrum, the most common findings are perforation of the eardrum (49 ears) either in the posterosuperior marginal $(46 \%)$ or in the attic $(52 \%)$ (Figure-2). These findings of posterosuperior marginal perforation in eardrum are higher. Study done by Roland PS found that attic perforation $60 \%$ cases and marginal perforation $40 \%$ case which is similar to this study ${ }^{10}$. Regarding complications, it is observed in this series that only $12 \%$ cases presented with intracranial complications, three with meningitis, one with extradural abscess, one with lateral sinus thrombophlebitis and one with temporal lobe abscess. Almost one-fourth of the total cases presented with extracranial complications, 06 with post auricular abscess and 05 with postaural discharging sinus and 02 with facial nerve palsy. Study done by Kemppainen $\mathrm{HO}$ et al revealed that $25 \%$ cases presented with extracranial complication. Most of them were post auricular abscess and discharging sinus which is similar to this study ${ }^{11,16}$ but inconsistent with the studies ${ }^{17,18}$ who found intracranial complications around $12 \%$ of Cholesteatoma (Active squamous chronic otitis media). In this series, it supports the late presentation of cholesteatoma (Active squamous chronic otitis media) in Bangladesh ${ }^{17,18}$.

Regarding the site and extension of cholesteatoma, it was found that $48.98 \%$ had involvement of the whole middle ear cleft, $28.58 \%$ had involved middle ear, attic, aditus and antrum ${ }^{11,16}$. Cholesteatoma localized in the attic, aditus and middle ear region $22.44 \%$ cases. One patient had retraction pocket with pearly white debris in parsflaccida.

This can be explained by the fact that the late presentation of cholesteatoma allows it to extend into the different parts of middle ear cleft. As per imaging $X$-ray mastoid Towne's and Stenver's (Table- $X$ ) view revealed well circumscribed cavity in 35 patients $(70 \%)$. In CT scan of tympanomastoid region and brain (Table-XI) well circumscribed cavity in tympanomastoid region with ossicular chain erosion was found in 18 patients $(90 \%)$ and abscess (temporal lobe + extradural) was found in 02 cases $(10 \%)$ as per the audio logical findings maximum patients had moderate conductive type of deafness $(74.47 \%)$ (Figure-3) followed by mild conductive deafness $(19.15 \%)$ and a few with mixed deafness (6.38\%).About surgical treatment; most of the patient had undergone modified radical mastoidectomy $(91.84 \%)$. A few patient $(6.12 \%)$ required radical mastoidectomy due to associated intracranial complications (Table-XII). One patient was treated conservatively by regular microscopic suction clearance with high magnification as because they were limited cholesteatoma in the attic early and positive diagnosis of cholesteatoma by clinical examination and timely intervention is imperative for the eradication of the disease and lessening its complication, thus saving thousands of lives. We suggest every practitioner should have an otoscope to screen out cholesteatoma (Active squamous chronic otitis media).

\section{Conclusion}

Cholesteatoma is not an uncommon disease in Bangladesh. Cholesteatoma requires time to develop, being the earliest cases diagnosed at the age of 6 years and maximum age of 
about 40 years in this study. Most of the patients presented with multiple symptoms with or without complications. Hearing impairment, foul smelling, scanty yellowish or bloodstained discharge of long duration are found in most patients. Cholesteatoma with complications are found in relatively low age group, residing in the rural areas in overcrowded unhygienic condition and suffering from malnutrition, illiteracy and ignorance about the primary health care are sufferers of this dreadful disease. Early and prompt diagnosis of cholesteatoma by clinical examination and timely intervention are imperative for the eradication of the disease and lessening its complication, thus saving thousands of lives.

\section{References}

1. Browning GG, Merchant SN, Kelly G et al. Chronic otitis media. In: Gleeson M, editor. Scott-Brown's Otolaryngology, 7th ed, London. Arnold 2008; 3:3396-3401.

2. Cawthorne T. Congenital cholesteatoma. Acta oto-rhinolaryngologica Belgica 1971; 25(6):833-6.

3. McDonald TJ, Cody DT, Ryan Jr RE. Congenital cholesteatoma of the ear. Annals of Otology, Rhinology \& Laryngology 1984; 93(6):637-40.

4. Jackler RK. The surgical anatomy of cholesteatoma. Otolaryngologic clinics of North America 1989; 22(5):883-96.

5. Sadé J, Shatz A. Cholesteatoma in children. J Laryngol Otol 1988; 102(11):1003-6.

6. Roger F. Gray, Mautice Howthorne. editors, Synopsis of Otolaryngology 5th ed, 1992.

7. Alan G Kerr, John B, editors. Scot Brown's Otolaryngology, Otology 6th edn Butterworth and Heinemanna, 1997.

8. Herald Ludman Tony wright, Editors, Disease of the ear, 6th ed, 1998.
9. Ballenger JJ. Disease of ear nose and throat. Head neck, 13th ed. Philadepiphia Lea and Fabiger 1985:11360-42.

10. Roland PS. Middle ear Cholesteatoma. Available at http://emedicine.medscape.com. article//860080-overview.

11. Shenoi PM. Management of chronic suppurative otitis media. Scott-Brown's Otolaryngology, 6th ed. Oxford, London, Boston, Butterworth-Heinemann 1987:215-37.

12. Cody TR, Taylor WF. Mastoidectomy for acquired cholesteatoma Long term results. In: McCabe BF, Sade J, Abramson M, editors. Cholesteatoma (Active squamous chronic otitis media), Ist International Conference, Birmingham, Alabama. Aesculapius Publishied Co 1977; 33: 51.

13. Ludman $\mathrm{H}$. Complication of suppurative otitis media. Booth JB, editor. Scott Brown's Otolairyngology, 5th ed. London: Butterworth 1987; 3:264-91.

14. Chowdhury MA, Alauddin M. Comparative study between tubotympanic and atticoantral types of chronic suppurative otitis media. Bangladesh Medical Research Council bulletin 2002; 28(1):36-44.

15. Kangsanarak J, Fooanant S, Ruckphaopunt $\mathrm{K}$ et al. Extracranial and intracranial complications of suppurative otitis media. Report of 102 cases. The Journal of Laryngology \& Otology 1993; 107(11):999-1004.

16. Kemppainen HO, Puhakka HJ, Laippala PJ et al. Epidemiology and aetiology of middle ear cholesteatoma. Acta oto-laryngologica 1999; 119(5):568-72.

17. Nyrop M, Bonding P. Extensive cholesteatoma: Long-term results of three surgical techniques. The Journal of Laryngology \& Otology 1997; 111(6):521-6.

18. Alho OP, Jokinen K, Laitakari K et al. Chronic suppurative otitis media and cholesteatoma. Vanishing diseases among Western populations?. Clinical Otolaryngology \& Allied Sciences 1997; 22(4):358-61. 